\title{
PENGARUH KEPEMIMPINAN DAN BUDAYA ORGANISASI TEHADAP KINERJA PEGAWAI PADA HOTEL NON BINTANG DI BANDUNG
}

\author{
Imas Komariyah \\ Fakultas Ekonomi Universitas Wanita Internasional Bandung \\ Email: imaskomariah123@gmail.com
}

\begin{abstract}
This study aimed to analyze the effect of transformational leadership, organizational culture toward employee performance. Sampling in this study using a Stratified Random Sampling and the size of 92 respondents, methods of analysis use path Analysis.

The results showed that based on the preception of respondents, the overall variable transformotional leadership in the category quite well toward good, look that variable tranformational leadership $\left(X_{1}\right)$ has a direct amount to $13,62 \%$, indirect effect throught its realtionship culture organization $\left(X_{2}\right)$ amount to 11,30 , and total the effect $24,92 \%$. Culture organitation has a direct amount to 29,38\%, indirect effect throught its relationship tranformational leadership $11,30 \%$ and total the effect $40,68 \%$. The coefecient of determination calculation result is equal to $65,59 \%$.

The result of reseach concludes that there are partially and stimultaneously significant effect of transformational leadership variable, organizational culture toward employee performance.
\end{abstract}

Keywords : Leadership and Organizational Culture Tehadap Employee Performance

\section{PENDAHULUAN}

ektor kepariwisataan merupakan sektor yang dapat menunjang terhadap perekonomian masyarakat Indonesia, perhotelan salah satunya dapat menunjang pendapatan daerah. Mengingat begitu pentingnya pariwisata di Indonesia, maka pariwisata ini sendiri diatur khusus dalam Undang-Undang Republik Indonesia, Nomor 10 Tahun 2009, dimana dalam Pasal 4 disebutkan bahwa Kepariwisataan bertujuan untuk meningkatkan pertumbuhan ekonomi, meningkatkan kesejahteraan rakyat, menghapus kemiskinan, mengatasi pengangguran, melestarikan alam, lingkungan, dan sumber daya, memajukan kebudayaan, mengangkat citra bangsa, memupuk rasa cinta tanah air, 
memperkukuh jati diri dan kesatuan bangsa, serta mempererat persahabatan antar bangsa.

Dalam Inpres RI. Nomor 16 Tahun 2005 tentang Kebijakan Pembangunan Kebudayaan dan Pariwisata, tercantum juga dalam UU Nomor 10 Tahun 2009 tentang Kepariwisataan. Dalam PP No. 25 Tahun 2000, tentang standar dan norma kepariwisataan bersifat nasional sehingga pengaturan masih dilaksanakan di Pemerintah Pusat.

Perkembangan Hotel tidak terlepas dari Sumber Daya Manusia, karena SDM merupakan assets yang dapat mendukung keberhasilan perusahaan. Faktor utama dalam peningkatan SDM melalui peningkatan kinerja pegawai yang didukung dengan peningkatan kompetensi pegawai, kepemimpinan, dan budaya organisasi, dari semua variabel ini yang dapat menunjang tehadap peningkatan kinerja pegawai, dan dapat menghasilkan peningkatan kualitas SDM.

Berdasarkan hasil pengamatan melalui kuesioner pra penelitian terhadap 20 responden dari delapan Hotel Non-Bintang (Hotel Nalendra, Hotel Sepuluh, Hotel Lodaya, Hotel Sawung Galing, Cihampelas 1, Cihampelas 2, Hotel Puma, Hotel Cpaganti, di Bandung) sebagai berikut: 21\% menyatakan sangat setuju bahwa mereka bekerja berdasarkan perencanaan, 19\% menyatakan setuju mereka bekerja sesuai perencanaan, $38 \%$ menyatakan setuju mereka bekerja sesuai perencanaan, $13 \%$ menyatakan setuju mereka bekerja berdasarkan perencanaan, 9\% menyatakan tidak setuju mereka bekerja berdasarkan perencanaan.

Dari penelitian awal ini menunjukkan bahwa mereka pada umumnya tidak mengetahui perencanaan dan indikator yang harus dicapai. Jika mereka sendiri tidak mengetahui indikator tersebut menunjukkan bahwa mereka tidak ada tuntutan kinerja yang jelas.

Hasil-hasil yang dicapai perusahaan ditunjukan dari kinerja pegawai itu sendiri, tercapaianya kinerja bukan hanya didasarkan pada keahlian pegawai saja, tetapi tingkat kemampuan pegawai yang didukung oleh dorongan yang kuat dari pimpinan serta sesuai dengan prosedur dan perencanaan kerja pada organisasi itu sendiri.

Kinerja merupakan suatu fungsi dari motivasi dan kemampuan. Untuk menyelesaikan tugas atau pekerjaan seseorang, sepatutnya memiliki tingkat kesediaan dan tingkat kemampuan tertentu. Kesediaan dan QE Journal | Vol.06 - No. 03 December 2017 - 189 
keterampilan seseorang tidaklah cukup efektif untuk mengerjakan sesuatu tanpa pemahaman yang jelas tentang apa yang akan dikerjakan dan bagaimana mengerjakannya. Kinerja merupakan perlaku nyata yang ditampilkan setiap orang sebagai prestasi kerja yang dihasilkan oleh karyawan sesuai dengan perannya dalam perusahaan. Kinerja karyawan merupakan suatu hal yang sangat penting dalam upaya perusahaan untuk mencapai tujuannya. (Rivai dan Sagala,2009:h,548).

Menurut Amstrong dan Baron dalam Wibowo (2010:2), menyatakan, "Kinerja merupakan hasil pekerjaan yang mempunyai hubungan kuat dengan tujuan strategis organisasi, kepuasan konsumen, dan memberikan kontribusi pada ekonomi", Lebih lanjut Wibowo menyatakan bahwa, "Kinerja adalah tentang melakukan pekerjaan dan hasil yang dicapai dari pekerjaan tersebut. Kinerja adalah tentang apa yang dikerjakan dan bagaimana cara mengerjakannya.

Pengukuran kinerja dapat diukur dengan beberapa dimensi, hal ini sesuai dengan pendapat Dharma (2003:355), cara pengukuran kinerja sebagai berikut: 1) Kuantitas, yaitu jumlah yang harus diselesaikan atau dicapai. Pengukuran Kuantitatif melibatkan perhitungan keluaran dari proses atau pelaksanaan kegiatan ini berkaitan dengan jumlah keluaran yang dihasilkan, 2) Kualitas, yaitu mutu yang harus dihasilkan (baik tidaknya). Pengukuran kualitatif keluaran mencerminkan pengukuran "tingkat kepuasan", yaitu seberapa baik penyelesaiannya, Ini berkaitan dengan bentuk keluaran, 3) Ketepatan waktu, yaitu sesuai tidaknya dengan waktu yang direncanakan. Pengukuran ketepatan waktu merupakan jenis khusus dari pengukuran kuantitatif yang menentukan ketepatan waktu penyelesaian suatu tugas.

Seperti yang telah dikemukan di atas bahwa faktor tercapainya kinerja pegawai dipengaruhi juga oleh faktor kepemimpinan, pemimpin yang bijaksana dan adil dan dapat dicintai dan dihargai oleh karyawannya inilah yang akan menjadi infirasi bagi bawahannya, kepemimpinan yang baik akan tercermin pada gaya kepemimpinan yang ditunjukkan oleh seorang pemimpin, seperti salah satu gaya kepemimpinan yaitu kepemimpinan transformasional. 
Pemimpin transformasional, pemimpin yang dibedakan oleh kemampuan istimewa mereka untuk memunculkan inovasi dan perubahan. (Daft, 2010:h,349),

Robbins, (2003:472) mengatakan, kepemimpinan Transformasional adalah pemimpin yang menginspirasi para pengikut untuk melampaui kepentingan pribadi mereka dan yang mampu membawa dampak mendalam dan luar biasa pada para pengikut.

Dimensi yang berkaitan dengan kepemimpinan transformasional menurut Menurut Bass dan Avolio (2003:94), mengidentifikasikan kepemimpinan transformasional ada empat komponen yaitu: Karisma (Idealized Influence), Motivasi Inspirasi (Inspirational motivation), Rangsangan/Stimulasi Intelektual (Intelectual stimulation), Perhatian Individual (Individualized consideration).

Budaya yang kuat akan mendorong terjadinya perubahan yang baik pada kienerja pegawai, maju mundurnya suatu organisasi disebabkan oleh perubahan-perubahan budaya yang ada dalam organisasi itu sendiri, hal ini sesuai dengan pendapat Wibowo (2011:1-3), yang mengatakan bahwa budaya dalam suatu organisasi mencerminkan penampilan organisasi bagaimana organisasi dilihat oleh orang yang berada diluarnya. Organisasi yang mempunyai budaya positif akan menunjukkan ciri positif pula, demikian pula sebaliknya apabila budaya organisasi tidak berjalan baik akan memberikan citra negatif bagi organisasi. Budaya organisasi tumbuh melalui proses evolusi dari gagasan yang diciptakan oleh pendiri organisasi dan kemudian ditanamkan kepada para pengikutnya. Budaya organisasi tumbuh, dan berkembang dilakukan dengan menanamkan melalui proses pembelajaran dan pengalaman

Sedangkan Harist (2009:220) mengatakan bahwa, Budaya organisasi adalah berdasarkan pada nilai-nilai yang bertahan lama yang terwujud di dalam norma-norma, aturan-aturan, SOP (Standar Operation Procedure) dan tujuan organisasi. Orang-orang di dalam organisasi selalu mencerminkan nilai-nilai budaya ini di dalam tindakan-tindakan dan keputusankeputusan mereka dan juga pada saat mereka menghadapi ambiguitas dan ketidakpastian yang ada di dalam maupun di luar organisasi. Nilai-nilai yang terkandung di dalam budaya organisasi merupakan pembentuk perilaku dan respons para anggota terhadap berbagai situasi dan 
meningkatkan kehandalan perilaku para anggota. Dalam konteks ini kehandalan belum tentu berarti patuh atau berperilaku secara konsisten melainkan juga dapat berarti berperilaku inovatif atau kreatif secara konsisten.

Dimensi yang digunakan dalam budaya organisasi Sedangkan menurut Denison's dalam Schein (2004:169), dari hasil survey membagi dalam dua belas dimensi dalam empat bagian umum, yaitu sebagai berikut: Misi (Mission), Konsisten (Consistency), Penyesuaian (Adaptability), Keterlibatan (Involvement).

\section{METODE PENELITIAN}

Metode yang digunakan dalam penelitian ini metode deskriptif dan metode verifikatif. Penelitian deskriptif adalah peneltian yang bertujuan untuk memperoleh deskripsi tentang ciri-ciri variabel kepemimpinan transformasional, budaya organisasi dan kinerja pegawai. Sedangkan penelitian verifikatif adalah untuk menghitung besaran pengaruh bebas terhadap variabel terikat dan sekaligus menguji kebenaran suatu hipotesis yang dilaksanakan melalui pengumpulan data di lapangan, dimana dalam penelitian ini akan menguji pengaruh kepemimpinan transformasional, budaya organisasi, dan kinerja pegawai pada Hotel Non-Bintang Bandung.

Mengingat penelitian ini menggunakan deskriptif dan verifikatif maka metode penelitian yang digunakan adalah metode descriptive survey dan explanatory survey. Penelitian ini meneliti data crossectional, yaitu informasi dari sebagian populasi (sampel responden) dikumpulkan langsung dari lokasi secara empirik pada kurun waktu tertentu.

Variabel yang diteliti dalam penelitian ini dibagi dalam 3 (tiga kelompok) sebagai berikut:

1) Variabel pertama (independent variable /variabel penyebab) terdiri dari, Kepemimpinan Transformasional ( $\left.\mathrm{X}_{1}\right)$, dengan dimensi yang digunakan yaitu: 1) pengaruh Ideal (idealized influence), 2) motivasi inspirasional (inspirasional motivation), 3) stimulasi Intelektual (intelectual stimulation), 4) perhatian Individu (individualized consideration). Budaya Organisasi $\left(\mathrm{X}_{2}\right)$, (missi) dan konsisten (consistency) dibanding dengan dimensi lainnya, artinya kedua dimensi dipertahankan, dan dimensi adaptasi (adaptation) dan keterlibatan (involvement) ditingkatkan. 
2) Variabel kedua (dependent variable/variabel terikat) yaitu: Kinerja Pegawai $(Y)$ dengan dimensi yang digunakan: kuantitas, kualitas,dan ketepatan waktu.

Untuk meneliti pengaruh kepemimpinan transformasional, budaya organisasi, dan kinerja pegawai diperlukan data primer. Untuk mendapatkan data primer tersebut digunakan teknik pengumpulan data sebagai berikut.

Berdasarkan hasil penelitian jumlah pegawai hotel 120 pegawai, untuk me menggunakan ukuran sampel dalam penelitian digunakan rumus slovin, dengan tingkat errovar $5 \%$ dan hasil responden 92 pegawai.

\section{$\underline{\text { Rancangan Analisis Data }}$}

Pengujian instrumen dilakukan dengan uji validitas, uji reliabilitas dan uji normalitas

Tabel 1.1 Uji Validitas Variabel Kepemimpinan Transformasional $\left(\mathrm{X}_{1}\right)$

\begin{tabular}{|c|c|c|c|}
\hline Pernyataan & $\mathbf{r}$ hitung & $\mathbf{r}$ kritis & Keterangan \\
\hline $\mathrm{X}_{1.1}$ & 0,415 & 0,300 & Valid \\
\hline$X_{1.2}$ & 0,607 & 0,300 & Valid \\
\hline$X_{1.3}$ & 0,375 & 0,300 & Valid \\
\hline $\mathrm{X}_{1.4}$ & 0,531 & 0,300 & Valid \\
\hline$X_{1.5}$ & 0,549 & 0,300 & Valid \\
\hline$X_{1} .6$ & 0,505 & 0,300 & Valid \\
\hline $\mathrm{X}_{1.7}$ & 0,434 & 0,300 & Valid \\
\hline $\mathrm{X}_{1.8}$ & 0,420 & 0,300 & Valid \\
\hline$X_{1.9}$ & 0,376 & 0,300 & Valid \\
\hline $\mathrm{X}_{1.10}$ & 0,621 & 0,300 & Valid \\
\hline $\mathrm{X}_{1.11}$ & 0,535 & 0,300 & Valid \\
\hline $\mathrm{X}_{1.12}$ & 0,561 & 0,300 & Valid \\
\hline $\mathrm{X}_{1.13}$ & 0,543 & 0,300 & Valid \\
\hline $\mathrm{X}_{1.14}$ & 0,465 & 0,300 & Valid \\
\hline $\mathrm{X}_{1.15}$ & 0,501 & 0,300 & Valid \\
\hline
\end{tabular}

Sumber : Hasil Pengolahan SPSS 20

Berdasarkan data di atas menunjukkan bahwa uji validitas seluruh pernyataan dari 15 pernyataan variabel kepemimpinan transformasional menunjukkan valid yaitu $r$ hitung $\geq r$ tabel, dimana nilai validitas terkecil pada 
pernyataan $X_{1.3}$ yaitu sebesar 0,375 dan nilai validitas terbesar pada pernyataan $X_{1.2}$ yaitu sebesar 0,607 .

Tabel 1.2 Uji Validitas Variabel Budaya Organisasi $\left(X_{2}\right)$

\begin{tabular}{cccc}
\hline Pernyataan & r hitung & r kritis & Keterangan \\
\hline $\mathrm{X}_{2.1}$ & 0,416 & 0,300 & Valid \\
$\mathrm{X}_{2.2}$ & 0,436 & 0,300 & Valid \\
$\mathrm{X}_{2.3}$ & 0,304 & 0,300 & Valid \\
$\mathrm{X}_{2 .}$ & 0,439 & 0,300 & Valid \\
$\mathrm{X}_{2.5}$ & 0,431 & 0,300 & Valid \\
$\mathrm{X}_{2 .} .6$ & 0,543 & 0,300 & Valid \\
$\mathrm{X}_{2} .7$ & 0,381 & 0,300 & Valid \\
$\mathrm{X}_{2} .8$ & 0,365 & 0,300 & Valid \\
$\mathrm{X}_{2 .}$ & 0,424 & 0,300 & Valid \\
$\mathrm{X}_{2} .10$ & 0,495 & 0,300 & Valid \\
$\mathrm{X}_{2} .11$ & 0,477 & 0,300 & Valid \\
$\mathrm{X}_{2} .12$ & 0,637 & 0,300 & Valid \\
$\mathrm{X}_{2.13}$ & 0,584 & 0,300 & Valid \\
$\mathrm{X}_{2.14}$ & 0,530 & 0,300 & Valid \\
$\mathrm{X}_{2.15}$ & 0,407 & 0,300 & Valid \\
\hline
\end{tabular}

Sumber : Hasil pengolahan SPSS 20

Berdasarkan data di atas menunjukkan bahwa uji validitas seluruh pernyataan dari 15 pernyataan variabel budaya organisasi menunjukkan valid yaitu $\mathrm{r}$ hitung $\geq \mathrm{r}$ tabel, dimana nilai validitas terkecil pada pernyataan $\mathrm{X}_{2.3}$ yaitu sebesar 0,304 dan nilai validitas terbesar pada pernyataan $\mathrm{X}_{2.12}$ yaitu sebesar 0,637 .

Tabel 1.3 Uji Validitas Variabel Kinerja Pegawai (Y)

\begin{tabular}{cccc}
\hline Pernyataan & rhitung & rtabel & Keterangan \\
\hline Y.1 & 0,333 & 0,300 & Valid \\
Y.2 & 0,582 & 0,300 & Valid \\
Y.3 & 0,421 & 0,300 & Valid \\
Y.4 & 0,499 & 0,300 & Valid \\
Y.5 & 0,434 & 0,300 & Valid \\
Y.6 & 0,683 & 0,300 & Valid \\
Y.7 & 0,406 & 0,300 & Valid \\
Y.8 & 0,378 & 0,300 & Valid \\
Y.9 & 0,672 & 0,300 & Valid \\
Y.10 & 0,384 & 0,300 & Valid
\end{tabular}

QE Journal | Vol.06 - N o. 03 December 2017 - 194 


\begin{tabular}{cccc} 
Y.11 & 0,400 & 0,300 & Valid \\
Y.12 & 0,589 & 0,300 & Valid \\
Y.13 & 0,440 & 0,300 & Valid \\
Y.14 & 0,421 & 0,300 & Valid \\
Y.15 & 0,506 & 0,300 & Valid \\
Y.16 & 0,514 & 0.300 & Valid \\
Y.17 & 0,336 & 0,300 & Valid \\
\hline
\end{tabular}

Sumber : Hasil pengolahan SPSS 20

Berdasarkan data di atas menunjukkan bahwa uji validitas seluruh pernyataan dari 17 pernyataan variabel kinerja karyawan menunjukkan valid yaitu $r$ hitung $\geq r$ tabel, dimana nilai validitas terkecil pada pernyataan Y1.1 yaitu sebesar 0,333 dan nilai validitas terbesar pada pernyataan $Y_{2.6}$ yaitu sebesar 0,683.

\section{HASIL DAN PEMBAHASAN}

\section{Analisis Deskriptif}

Untuk mengukur tingkat penafsiran menurut J. Supranto 2001 sebagai berikut, 4,2 -5,0 sangat baik, 3,4 -4,1 baik, 2,6-3,3 cukup baik, 1,8 -2,5 kurang baik, 1,0-1,7 sangat tidak baik.

Kepemimpinan Transformasional

Hasil analisis deskriptif menunjukkan bahwa tingkat total skor seluruh dimensi kepemimpinan transformasional sebesar 11,159, dan jumlah ratarata 3,44, maka jika merujuk pada kriteria penafsiran kepemimpinan transformasional pada kriteria baik, seperti tertera pada tabel di bawah ini.

Tabel 1.4 Rekapitulasi Tanggapan Responden Tentang Kepemimpinan Transformasional

\begin{tabular}{|c|c|c|c|c|c|}
\hline No & Dimensi & $\Sigma$ Skor & $\begin{array}{c}\text { Jumlah } \\
\text { Pernyataan }\end{array}$ & $\begin{array}{l}\text { Rata- } \\
\text { Rata }\end{array}$ & Kriteria \\
\hline 1 & Pengaruh Ideal & 2,333 & 3 & 3,57 & Baik \\
\hline 2 & $\begin{array}{l}\text { Motivasi } \\
\text { Inspirasional }\end{array}$ & 2,485 & 3 & 3,80 & Baik \\
\hline 3 & $\begin{array}{l}\text { Stimulasi } \\
\text { Intelektual }\end{array}$ & 3,386 & 4 & 3,88 & Baik \\
\hline \multirow[t]{2}{*}{4} & $\begin{array}{l}\text { Perhatian } \\
\text { Individu }\end{array}$ & 2,955 & 5 & 2,71 & $\begin{array}{c}\text { Cukup } \\
\text { Baik }\end{array}$ \\
\hline & Kepemimpinan & 11,159 & 15 & 3,44 & Baik \\
\hline
\end{tabular}


Transformasional

Sumber: Hasil Pengolahan Data

\section{Budaya Organisasi}

Hasil analisis deskriptif menunjukkan bahwa tingkat total skor seluruh dimensi budaya organisasi sebesar 11,861 dan jumlah rata-rata 3,61, maka jika merujuk pada kriteria penafsiran budaya organisasi pada kriteria kuat, seperti tertera pada tabel di bawah ini.

Tabel 1.5 Rekapitulasi Tanggapan Responden Tentang Budaya Organisasi

\begin{tabular}{clcccl}
\hline No & Dimensi & $\Sigma$ Skor & $\begin{array}{c}\text { Jumlah } \\
\text { Pernyataan }\end{array}$ & Rata-Rata & Kriteria \\
\hline 1 & Misi & 2,830 & 3 & 4,33 & Sangat Kuat \\
2 & Konsisten & 4,226 & 5 & 3,87 & Kuat \\
3 & Adaptasi & 2,830 & 4 & 3,24 & Cukup Kuat \\
4 & Keterlibatan & 1,975 & 3 & 3,02 & Cukup Kuat \\
\hline & Budaya & 11,861 & 15 & 3,61 & Kuat \\
& Organisasi & & & & \\
\hline
\end{tabular}

Sumber: Hasil Pengolahan Data

\section{Kinerja Pegawai}

Hasil analisis deskriptif menunjukkan bahwa tingkat total skor seluruh dimensi kinerja pegawai sebesar 11,861 dan jumlah rata-rata 3,61, maka jika merujuk pada kriteria penafsiran kinerja pegawai pada kriteria baik, seperti tertera pada tabel di bawah ini

Tabel 1.6. Rekapitulasi Tanggapan Responden Tentang Kinerja Pegawai

\begin{tabular}{|c|c|c|c|c|c|}
\hline No & Dimensi & $\Sigma$ Skor & $\begin{array}{c}\text { Jumlah } \\
\text { Pernyataan }\end{array}$ & Rata-Rata & Kriteria \\
\hline \multirow{4}{*}{$\begin{array}{l}1 \\
2 \\
3\end{array}$} & Kualitas & 3,894 & 5 & 3,57 & Baik \\
\hline & Kuantitas & 3,231 & 5 & 3,60 & Baik \\
\hline & $\begin{array}{l}\text { Ketepatan } \\
\text { Waktu }\end{array}$ & 5,564 & 7 & 3,64 & Baik \\
\hline & $\begin{array}{l}\text { Kinerja } \\
\text { Pegawai }\end{array}$ & 12,689 & 15 & 3,60 & Baik \\
\hline
\end{tabular}

Sumber: Hasil Pengolahan Data 


\section{$\underline{\text { Analisa Korelasi }}$}

Berdasarkan hasil analisa korelasi antara variabel kepemimpinan transformasional dengan budaya organisasi sebesar 0,565, jika merujuk pada kriteria penanfsiran korelasi kedua variabel tersebut cukup kuat.

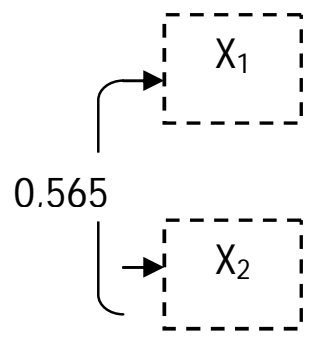

\section{$\underline{\text { Analisis Verifikatif }}$}

Berdasarkan hasil analisis verifikatif menunjukkan bahwa pengaruh Kepemimpinan Transformasional $\left(\mathrm{X}_{1}\right)$, Budaya Organisasi $\left(\mathrm{X}_{2}\right)$, terhadap Kinerja Pegawai (Y) Secara Simultan dan Parsial

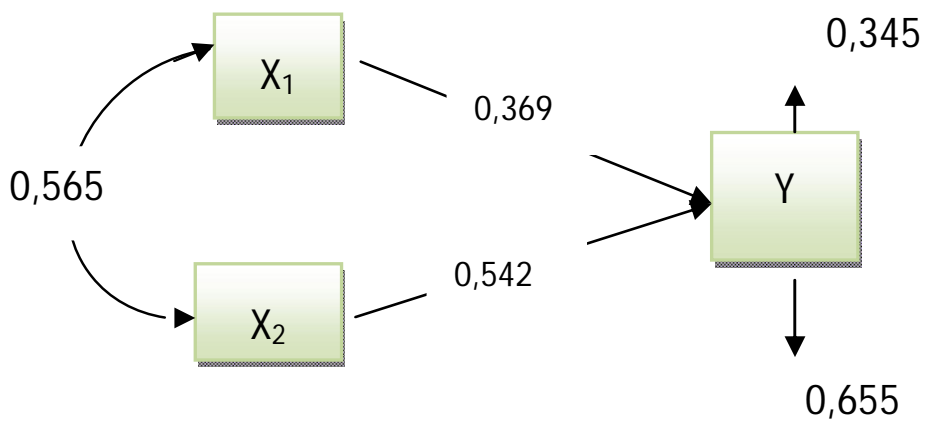

Berdasarkan hasil pengolahan data dengan menggunakan program SPSS 20, menunjukkan koefisien jalur kepemimpinan transformasional $\left(X_{1}\right)$ sebesar 0,369 atau $36,9 \%$, dan koefesien jalur budaya organisasi $\left(\mathrm{X}_{2}\right)$ sebesar 0,542 atau $54,2 \%$, sedangkan pengaruh koefesien determinasi $\left(\mathrm{R}^{2}\right)$ kepemimpinan transformasional $\left(\mathrm{X}_{1}\right)$ dan budaya organisasi $\left(\mathrm{X}_{2}\right)$ terhadap kinerja pegawai $(\mathrm{Y})$ secara simultan sebesar 0,655 atau $65,5 \%$ dengan errovar 0,345 atau $34,5 \%$. 
Dalam perhitungan nilai korelasi dan koefisien jalur yang telah dilakukan, maka dapat diketahui besarnya pengaruh langsung maupun tidak langsung kepemimpinan transformasional, budaya organisasi terhadap kinerja pegawai sebagai berikut:

Pengaruh Langsung dan Tidak Langsung Kepemimpinan Transformasional, Budaya Organisasi, Terhadap Kinerja Pegawai

Tabel 1.7 Pengaruh Langsung dan Tidak Langsung Kepemimpinan Transformasional, Budaya Organisasi, Terhadap Kinerja Pegawai

\begin{tabular}{|c|c|c|c|c|}
\hline \multirow[t]{2}{*}{ Variabel } & \multirow{2}{*}{$\begin{array}{l}\text { Pengaruh } \\
\text { Langsung }\end{array}$} & \multicolumn{2}{|c|}{$\begin{array}{l}\text { Pengaruh Tidak } \\
\text { Langsung }\end{array}$} & \multirow{2}{*}{$\begin{array}{c}\text { Total } \\
\text { Pengaruh }\end{array}$} \\
\hline & & $X_{1}$ & $X_{2}$ & \\
\hline Kepemimpinan $\left(X_{1}\right)$ & $13,62 \%$ & - & $11,30 \%$ & $24,92 \%$ \\
\hline Budaya Organisasi & & & & \\
\hline$\left(X_{2}\right)$ & $29,38 \%$ & $11,30 \%$ & - & $40,68 \%$ \\
\hline Total & $42,99 \%$ & $11,30 \%$ & $11,30 \%$ & $65,59 \%$ \\
\hline
\end{tabular}

Berdasarkan data di atas menunjukan bahwa pengaruh langsung kepemimpinan transformasional sebesar 13,62\%, pengaruh langsung budaya organisasi sebesar $29,38 \%$, dan pengaruh tidak langsung variabel kepemimpinan terhadap budaya organisasi masing-masing sebesar 11,30\%, Besaran pengaruh total (koefisien determinan) variabel kepemimpinan transformasional, budaya organisasi, dan terhadap kinerja pegawai sebesar 0,659 atau $65,59 \%$, artinya bahwa hasil tersebut menandakan bahwa $65,59 \%$ variabel kinerja pegawai dapat diterangkan dengan variabel kepemimpinan transformasional,dan budaya organisasi. Sedangkan sisanya $34,41 \%$ dipengaruhi oleh variabel lain di luar model yang tidak diteliti.

Hal ini menunjukkan kedua variabel tersebut berpengaruh terhadap peningkatan kinerja pegawai, sesuai dengan pendapat dengan teori yang dikemukakan Wibowo (2010:311) menyatakan bahwa: suatu organisasi biasanya dibentuk untuk mencapai suatu tujuan melalui kinerja segenap sumber daya manusia yang ada dalam organisasi. Namun, kinerja sumber daya manusia sangat ditentukan oleh kondisi lingkungan internal maupun ekternal organisasi, termasuk budaya organisasi. Karenanya kemampuan menciptakan suatu organisasi dengan budaya yang mampu mendorong kinerja adalah suatu kebutuhan. 


\section{SIMPULAN DAN SARAN}

Berdasarkan analisis data sekunder dan data primer serta hasil analisis jalur dan pengujian hipotesis dari data penelitian terhadap Hotel NonBintang pada delapan hotel di Kota Bandung, maka dapat disimpulkan sebagai berikut:

a. Kondisi kepemimpinan transformasional, budaya organisasi, terhadap kinerja pegawai.

1. Kepemimpinan Transformasional berada pada kriteria cukup baik sampai dengan baik, artinya kepemimpinan yang ada di Hotel NonBintang dinilai telah berjalan dengan baik. Tipe kepemimpinan yang ada telah menginfirasi dan memberikan peluang kepada pegawai agar dapat menunjukkan prestasi kerjanya. Namun demikian masih terdapat beberapa aspek kelemahan diantaranya: pimpinan kurang menghargai dan mengadopsi ide-ide gemilang dari pegawai, pimpinan kurang mempertinggi perasaan optimisme pegawai terhadap masa depan.

2. Budaya Organisasi berada pada kriteria cukup kuat sampai dengan sangat kuat, artinya budaya organisasi yang ada pada Hotel NonBintang sudah dijalankan secara baik, dengan terjadinya perubahan perilaku pegawai untuk terbentuknya citra yang telah ditentukan. Namun demikian masih terdapat beberapa aspek kelemahan diantaranya: dalam setiap proses perencanaan pimpinan kurang melibatkan pegawai,pegawai kurang mau beradaptasi dengan lingkungan yang baru.

3. Kinerja Pegawai berada pada kriteria cukup tinggi sampai dengan tinggi, artinya kinerja pegawai Hotel Non-Bintang secara umum cukup tinggi, ditunjukkan dengan adanya hasil kerja pegawai yang sesuai Standar Operating Procedure (SOP). Namun demikian masih terdapat beberapa hal yang menjadi kelemahan diantaranya pegawainya belum melakukan inovasi dalam melaksanakan pekerjaan yang diterima, pegawai kurang teliti dalam menjaga kualitas pekerjaan.dan kurang kreatif dalam melaksanakan pekerjaannya.

b. Pengaruh kepemimpinan transformasional, budaya organisasi, terhadap kinerja pegawai. 
1. Kepemimpinan transformasional dan budaya organisasi berpengaruh positif dan signifikan terhadap kinerja karyawan, artinya terbentuknya kepemimpinan transformasional mempunyai peranan penting dalam meningkatkan kinerja organisasi, kepemimpinan transformasional akan optimal bila didukung dengan budaya organisasi yang kuat.

2. Kepemimpinan transformasioal berpengaruh positif dan signifikan terhadap kinerja karyawan, dapat diartikan semakin optimal kepemimpinan transformasional akan mendorong pada meningkatnya kinerja karyawan. Kepemimpinan transformasional mempunyai pengaruh lebih kecil dibanding budaya organisasi terhadap kinerja karyawan, hal ini dikarenakan kepemimpinan transformasional pada Hotel Non-Bintang dapat meningkatkan kinerja pegawai.

3. Budaya Organisasi berpengaruh positif dan signifikan terhadap kinerja pegawai dapat diartikan semakin kuat budaya organisasi maka kinerja pegawai akan semakin meningkat. Budaya organisasi mempunyai pengaruh yang paling besar terhadap kinerja karyawan, hal ini dikarenakan budaya organisasi pada Hotel Non-Bintang dapat membentuk perilaku karyawan sehingga dalam melaksanakan pekerjaan baik dan sinergi, budaya organisasi yang kuat diharapkan dapat meningkatkan kinerja pegawai.

Berdasarkan kesimpulan hasil penelitian, untuk lebih meningkatkan pengaruh kepemimpinan transformasional, budaya organisasi terhadap kinerja pegawai di delapan Hotel Non Bintang Kota Bandung.

1. Kepemimpinan transformasional perlu dioptimalkan yaitu pimpinan harus menghargai dan mengadopsi ide-ide gemilang dari pegawai, pimpinan harus memperkuat perasaan optimisme pegawai terhadap masa depan.

2. Budaya Organisasi perlu diperkuat melalui dimensi keterlibatan, yitu dalam setiap proses perencanaan pimpinan perlu melibatkan pegawai, pegawai harus beradaptasi dengan lingkungan yang baru.

3. Kinerja pegawai harus ditingkatkan melalui dimensi kualitas, yaitu perlu melakukan inovasi dalam melaksanakan pekerjaan yang 
diterima, pegawai kurang teliti dalam menjaga kualitas pekerjaan.dan kurang kreatif dalam melaksanakan pekerjaannya.

\section{DAFTAR PUSTAKA}

Bass, BM,. Avolio B,J, Jung.,D.I., \& Berson Y. 2003. Predicting Unit Performance By Assessing Tranformasional And Transactional Leadership. Journal Of Applied Psychology, 88(2), pp. 207-218.

Daft, Richard L, 2010, Era Baru Manajemen, Ed.ke-9, Buku 2, Jakarta:Salemba Empat

Dharma, Surya, 2003, Pradigma Baru, Manajemen Sumber Daya Manusia, Amara Books, Yogyakarta

Harits, Bunyamin, 2009 "Teori Organisasi" Jilid 1, Penerbit Insani Press, Bandung

Rivai, Veithzal dan Sagala, Jauvani, Ella, 2009. Manajemen Sumber Daya Untuk Perusahaan Dari Teori ke Praktik. Rajawali Pers, Divisi Perguruan Tinggi, PT RajaGrafindo Persada.

Robbins Stephen, P. 2001, Organizational Behavior Concept Controversies and Application $12^{\text {th }}$, Editions New Jersey Prentice Hall International Inc.

Robbins Stephen, P. 2003. Organizational Behavior. Sixth Edition, New Jersey: Prentice Hall International,. Inc

Schein, Edgar H, 2004, Organizational Culture and Leadership, 3 th Edition, USA, Josseybass,

Wibowo, 2010, Manajemen Kinerja, Edisi Ketiga. Jakarta:Rajawali Pers

Wibowo "Budaya Organisasi: Sebuah Kebutuhan untuk Meningkatkan Kinerja Jangka Panjang" Edisi-ke -2, --Jakarta: Rajawali Pers, 2011. Faculty of Economic, University of Pattimura, Indonesia, Department of Business

\section{Undang-Undang/Peraturan}

Undang-Undang Republik Indonesia, Nomor 10 Tahun 2009, 
Inpres RI. Nomor 16 Tahun 2005 tentang Kebijakan Pembangunan Kebudayaan dan Pariwisata, UU Nomor 10 Tahun 2009 tentang Kepariwisataan. 